\title{
Dispute Resolution in the Case of Production Sharing Contract vs Tax Treaty (Case Study of Government of Indonesia vs Oil and Gas Contractors in Branch Profit Tax Issue)
}

\author{
Harry Budi Artono \\ Ministry of Finance \\ Directorate General of Taxation \\ Jakarta, Indonesia \\ harry.budiartono@gmail.com
}

\begin{abstract}
The dispute between Government of Indonesia and oil and gas contractors regarding branch profit tax rate has been the highlight of issues in the oil and gas industry since 2010, when BPK-RI (Indonesia's Audit Board) released its audit findings on Central Government Financial Statements for year 2009. BPK-RI found that there is potential loss of state income due to application of tax treaty rate by several oil and gas contractors, which are lower than normal tax rate. It became recurring findings which has not been settled to date. From the two of BPK-RI recommendation, to collect the underpayment of tax and to amend the relating PSC contract, only first recommendation give positive results through lengthy litigation process in tax court. The effort to amend the PSC contract has not a vail as the contractors reluctant to respond to the government requests. This paper will attempt to explore the cause of the dispute and to evaluate the available options for both parties to settle the long dispute by exploring the legal standing of both PSC and tax treaty including the tax court ruling from one of the finished case.
\end{abstract}

Keywords- oil and gas contractors and disputes resolution

\section{INTRODUCTION}

The dispute between the Government of Indonesia (GoI) and oil and gas contractors regarding the application of tax treaty's rate over the rate in the income tax law to calculate branch profit tax has occurred since 2010 and have not reached a final and binding conclusion for both parties to date. The rate of the branch profit tax in the treaties are lower in half, which is $10 \%$, than the actual rate as stated in the article 26 (4) of income tax law, which is $20 \%$.

The Audit Board of The Republic of Indonesia (BPK-RI) have highlighted these disputes in their Audit Report on Central Government Financial Statements from 2010 to 2016, particularly because this issue causing state income losses during those periods. Based on the audit reports, the Go I suffered losses of income from 2010 to 2016 as much as IDR 1.43 trillion, IDR 2.35 trillion, IDR 1.38 trillion, IDR 1.78 trillion, IDR 3.13 trillion, IDR 915.59 billion, and IDR 555.51 billion respectively[1]. The report also disclosed the contractors' that used the tax treaties ruling, along with their operational area. There are prominent corporation such as BP, ExxonMobil, Premier and Petronas, to less prominent such as Talisman, Salamander, and Kufpec. In total, there are 26 contractors from 12 operational areas that used the tax treaties ruling[1].

As a result of these findings, BPK-RI had issued recommendations to the GoI. The main recommendation are: 1) instructing the Directorate General of Taxes - MoF (DGT) to collect the underpayment of tax to the contractors; and 2) instructing the GoI through MEMR and SKK Migas to amend the PSCs of the contractors that exercise the tax treaty ruling in order to ensuring certainty in the PSC ruling as well as ensuring the GoI share from the petroleum income. Among the two recommendations, only the first that is able to executed by the GoI through tax litigation in the tax courts. However, the lengthy process of the litigation become the main obstacle as it needs approximately 3 to 5 years to reached a verdict. As a result, from all of the cases, only 9 cases had reached verdicts as of December 2017. 8 won the GoI and 1 won the contractor. On the other hand, GoI efforts to amend the PSC has not succeed as contractors did not respond to the GoI request.

Based on the above facts, this paper aims to evaluate the possible dispute resolution which can be taken to resolve it. In order to reach that, we will analyse the cause of the dispute, theoretically and historically, along with the legal standing of both the PSC and tax treaty. A look into the tax court ruling of one of the cases would also be done to attain the complete picture of the is sue.

\section{INDONESIA`S OIL AND GAS FISCAL REGIME}

\section{A. Concessions}

Indonesia has been known widely as one of the pioneer of the Production Sharing Agreement or PSC in the oil and gas industry in the world, and its PSC model are the most widely used to date. However, little known that, the first fiscal regime that used in Indonesia was concession.

Concession were first used in the mid-end of nineteenth century. First concession was given to Koninklijke Nederlansche Maatschappij tot Exploitatie van Petroleumbronnen in Nederlansch Indie (later it known as the Royal Dutch Company) in 1883 in North Sumatra. Later 
it was followed in East Kalimantan, South Sumatra, Central Java, and East Java[2]. At first, the concession was given by the King and Sultan before the Dutch issued the Dutch East Indies Mining Law (Indische Mijn Wet) on 1889 stated that all mining activities including oil and gas must obtain concession permit from the General Governor of Dutch East Indies.

The fiscal regime in the Indische Mijn Wet 1889 were: 1) concession period of at most 75 years; 2) the concession holder has to pay land rent to the colonial government; and 3) production fully belong to the concession holder with full right to sell freely without government control. Amendment were taken place on 1904 and 1918. Notable changes are: 1) concession period reduced to at most 40 years; 2) exc ise duty of $4 \%$ from the gross petroleum production introduced; and 3) $20 \%$ tax from the petroleum profit and $20 \%$ from the corporate profit also being imple mented. By the end of 1924, there were at least 119 concession permits issued by the Dutch Colonials. This fiscal regime continued until the enactment of the Law number 44/1960 which changed the concessions into contract of work.

\section{B. Contract of Work}

The contract of work presented many complexities as it obliged the concessions holder to release its concession rights and changed into contract of work. Several big contractors opposed this law and negotiation broke down. The first contract of work was signed by GoI, represented by Pertamin (Indonesia's National Oil Company) and Pan American on June 15, 1962. Notable clause in this contract are: 1) contract periods are 30 years; 2) cost allocation for year 1 to the year 8 for exploration phased were stated in the contract; 3) relinquishment of the operational area for $25 \%$ every 5 years; 4) signature bonus and production bonus payment to the government; 5) $60 \%$ of the corporate will be shared to the government [3].

Later in June 1963, the big contractors such as CPI, Shell, and Stanvac agreed to change its concession into this contract following the finalization of negotiation in Tokyo, this is known as the Tokyo Agreement. Several rulings introduced were still used in today's PSC, such as the contract period of 30 years and the Domestic Market Obligation (DMO) for contractors. Although, the fundamental aspect, which is control, are still fully in the contractors' hand, as it was in the concession regime.

\section{Production Sharing Contract}

In parallel with the enactment of the contract of work, Permina, another Indonesia NOC, were developing Production Sharing Contract (PSC). First PSC was signed between Permina and Asamera Oil (ind) Ltd. On September 1, 1961 for the B Block operational area in North Sumatra. In the mid 1960 it became the blue print of Indonesia's model PSC and standard petroleum fiscal regime for most developing-oil producer countries. As a result, from 1961 to 1975, there are 59 oil companies that operate under PSC regime.

The most fundamental difference in the PSC compared to the previous regimes is that the control or management of the petroleum operation belong to the state rather than the oil companies. It is stated in the Indonesia's law 8/1971 concerning Pertamina, which then further strengthened in the GR 35/1994 concerning requirements and cooperation guidance for oil and gas profit sharing contracts. The basic principles of PSC stipulated in those regulations are: 1) management of petroleum operation belong to Pertamina, as representatives of GoI; 2) contractor must have the necessary funding, technology and expertise for petroleum operation; 3) financial risks are borne by contractor; and, 4) the amount of profit sharing are determine based on the petroleum production level.

The fiscal regimes in the PSCs were modified time after time to suit to the market situation and domestic policy. In general, the PSC regimes can be classified into 3 generation. 1st generation (1961-1977), 2nd generation (1978-1987), and 3rd generation (1988-2001). The most notable regulation on 1st generation PSCs are:

1) Contractor would regain all of its expenditure and cost for petroleum operation, limited to maximum of $40 \%$ of its revenue.

2) Production, after deducted by cost recovery, will be shared with the amount of $65 \%$ for Pertamina and $35 \%$ for contractor, in which taxes are already included in the government share.

3) Contractor is oblige to surrender at maximu $25 \%$ of its production share to domestic market with a price of US\$ $0.20 /$ barrel.

4) Contractor must offer $10 \%$ of its interest to domestic companies when it's entering the commercial production phase.

Following these regulations, several contractors, particularly the US based contractors were having fiscal is sues related to the share proportion as the US fiscal systems did not recognise the tax included in the production share as income tax, but merely royalty. Thus, the US based contractors cannot claim it as tax credits for their tax payment in the US. Therefore, they asked their PSCs to be amended to separate the income tax calculation from the profit sharing. In other words, from net-after tax become gross-before tax. Another issue that they raised were the limitation of cost recovery to be lifted as it was not adhere to the Generally Accepted Accounting Procedure (GAAP).

In response to the contractors' demands, the GoI modified the 1st generation contract and introduced the 2nd generation PSC. The cost recovery limitation was lifted so that the contractor can recover all of its cost foregone before the production shared to the government. On the other hand, the production share percentage increased from $65 \%: 35 \%$ to $85 \%: 15$ followed by the separation of income tax calculation. The tax rate applied based on the prevailing rate at the signed date of the contract. In first phase of 2nd generation (1978-1983), the prevailing tax law was the 1978 tax law with CIT rate $45 \%$ and tax on interest, dividend and royalty (TIDR) rate $20 \%$ from profit after deducted by income tax (20\% x (Profit-CIT). Thus, the share percentage written on the PSC are no longer the net-after tax amount, which should be $85 \%: 15 \%$ for oil and $70 \%: 30 \%$ for gas, but a gross up-before tax rate, which are $65.91 \%$ for Pertamina and $34.09 \%$ for contractor.

In the second phase of the 2nd PSC generation (19841987), the production share rate is changed to 71.1538\%:28.8462\% for oil and 42.31\%:57.69\% for gas along with the application of the 1983 income tax law. From the profit share of $28.8462 \%$ and $57.69 \%$ contractor oblige to 
pay income tax rate of $48 \%$, which came from $35 \%$ CIT and branch profit tax of $13 \%(20 \%$ x profit after deducted by income tax). Therefore, the net-after tax amount of share among GoI and contractor would be kept same in the full amount at 85\%:15\% and 70\%:30 for oil and gas respectively[4]. Example of the calculation is as follows:

TABLE I. CALCULATION OF PROFIT SHARING

\begin{tabular}{|l|l|l|l|}
\hline \multicolumn{2}{|c|}{ Government } & \multicolumn{2}{c|}{ Contractors } \\
\hline \multicolumn{1}{|c|}{$\begin{array}{c}\text { Profit Share } \\
\text { Element }\end{array}$} & Percentage & \multicolumn{1}{c|}{$\begin{array}{c}\text { Profit Share } \\
\text { Element }\end{array}$} & Percentage \\
\hline $\begin{array}{l}\text { Gross Profit Share } \\
\text { (A) }\end{array}$ & $71.1538 \%$ & $\begin{array}{l}\text { Gross Profit } \\
\text { Share (A) }\end{array}$ & $28.8462 \%$ \\
\hline $\begin{array}{l}\text { Corp Income Tax } \\
(35 \%)\end{array}$ & $10.0962 \%$ & $\begin{array}{l}\text { Corp Income Tax } \\
(35 \%)\end{array}$ & $10.0962 \%$ \\
\hline $\begin{array}{l}\text { Branch Profit Tax } \\
\text { (C) }\end{array}$ & $3.75001 \%$ & $\begin{array}{l}\text { Branch Profit } \\
\text { Tax (C) }\end{array}$ & $3.75001 \%$ \\
\hline Taxes (D=B+C) & $13.84618 \%$ & Taxes (D=B+C) & $13.84618 \%$ \\
\hline $\begin{array}{l}\text { Nett Profit Share } \\
\text { (E=A+D) }\end{array}$ & $85 \%$ & $\begin{array}{l}\text { Nett Profit Share } \\
(\mathrm{E}=\mathrm{A}-\mathrm{D})\end{array}$ & $15 \%$ \\
\hline
\end{tabular}

The profit sharing formula aforementioned above also maintained in the 3rd generation PSC, although the rate may vary in several contracts. The prevailing tax rate also has dropped down to $44 \%$ in 1994 and then $40 \%$ in 2000 due to the amendment of income tax law, whereas the BPT rate is still kept the same at 20\% [5]. Other key regulation in this PSC generation are the enactment of First Tranche Petroleum (FTP) and Investment Credit.

From the above PSCs generation, the issues regarding the usage of tax treaty rate come from several PSCs that signed from 1978 to 2000. It is fair to conclude that the cause of the is sue is the change in the PSC fiscal regime particularly the written production share rate from net-after tax to grossbefore tax in the PSC. In addition to that, the separation of the tax calculation also creates a loophole in the legal standing of the PSC. Originally, it is clear that PSC is a commercial contract between GoI and oil and gas contractor, thus it is governed under the commercial law or agreement law, which are part of the civil law. After the separation, it is unclear as to which law should governed the PSC as tax law is part of the public law. This lack of clarity creates opportunity for contractor to use tax treaty rate to lower its BPT obligation.

\section{PSC AND TAX TREATY LEGAL ST ANDING}

PSC and tax treaty are both legal and binding agreement between contracting parties. PSC are business to government agreement (B to $G$ ), whereas tax treaty is government to government agreement ( $\mathrm{G}$ to $\mathrm{G})$. As both agreement signed by the Government confusion arise to determine which one is superior to the other and have the precedence to be obeyed.

\section{A. PSC legal standing}

There has been a lengthy debate as to whether PSC is a merely business agreement, thus governed by Indonesia's domestic law or actually an international agreement which is subject to international law. This multi-interpretation has been brought by several parliament members to the Constitutional Court to have a judicial review on Oil and Gas Law (Law 22/2001) in 2007. The phrase that was challenged is in article 11 (2), which states "Every Cooperation Contract that has been executed shall be notified in writing to the House of People's Representatives of the Republic of Indonesia (DPR/Parliament)." It is considered to violate the article 11 (2), 20(1), 33 (3) and 33 (4) of Indonesia Constitution 1945. The Constitutional Court corrected those interpretation by stating that:

"Although the article 11 (2) of Constitution states "The President in making other international agreements that will have an extensive and fundamental impact on the lives of the people which is linked to the state financial, and/or that requires an amend ment to or the enactment of a law, shall obtain the approval of the DPR", we agreed to the government and experts opinion presented in the court that the international agreement which is intended is the international agreement as define in the article 1 and 2 of 1969 VCLT and in the article 2 (1) point a of 1986 VCLT between states and international organizations. Therefore, Cooperation Contract as it stated in the article 11 (2) Oil and Gas Law, outside the scope of the definition of International agreement as it stipulated in the article 11 Constitution 1945. Thus, the pleader request regarding that matter has no sufficient basis."[6]

From the judicial review above, it is evident that PSC is a business contract between GoI and business entity, and not an international agreement. State can act as a sui genesis legal entity, in other words state can act as a both public entity and also private entity. State as a public entity occurred when it is act based on public interest or public governance (Iure imperri). On the other hand, state as a private entity is when it is involved in private or commercial act (Iure gestiones). The GoI action through Pertamina by concluding PSC agreement with oil and gas contractors is considered a private or commercial act, therefore the law that governed the contract is commercial law or agreement law, which in the domain of civil code, domestically and internationally.

Contract regulation is stipulated in the Indonesian Civil Code (ICC)/Burgerlijk Wetboek voor Indonesie enacted in 1848 in concordance with the civil code principles applied in the Netherlands at that time. As there is none civil code enacted, thus, the 1848 ICC provisions still applies to date. The consensual principle forms the bas is of the contract law under the civil code. According to the article 1320 of ICC a contract is valid only if it fulfils the following requirement:

a. Consent based on the free will of the parties

b. Concluded by legally competent parties

c. Agreed upon a definite object, which can be determine and traded

d. Agreed on a legal purpose, which not contravene with the law, morals, or public norms

Furthermore, article 1338 ICC stipulate that a contract that fulfils the requirement above is legally binding to the parties and cannot be changed or terminated without the consent of the parties (pacta sunt servanda). This article also stated that every contract must be performed in good faith [7].

The acknowledgement of PSC as binding agreement between parties by GoI is reflected in the article 33A verse (4) of Income Tax Law, which states:

"Income tax payable of Taxpayers who conduct business in the oil and natural gas, general mining 
sector and other mining sector under a Production Sharing Contract, Contract of Work or other cooperation agreement that remains valid at the time this law takes effect, shall be computed on the basis of the provisions contained in the Production Sharing Contract, Contract of Work or Cooperation Agreement until the termination of the contract or agreement."

The provision suggests that the GoI respect the sanctity of the contract and exclude other provisions in the law or regulations that might change the clauses in the agreement. Thus, it can be considered as a lex-specialis law.

\section{B. Tax Treaty legal standing}

Tax treaty is contractual agreement concluded between states in written form and governed by international law. This definition based on the Vienna Convention on the Law of Treaties 1969 (VCLT) which adopted internationally on 23 May 1969 and entered into force on 27 January 1980. The convention also sets the principles, process of concluding, and the formula. The VCLT has been ratified by 115 states as of November 2017, however, although Indonesia has acknowledged and concluded several treaties based on the VCLT principles, it has not signed nor ratified the VCLT yet. It considers the VCLT as part of customary international law and therefore considers itself bound by its provisions [8].

The authority of GoI to conclude tax treaty with other states is based on the Indonesia's 1945 Constitution article 11 verse (1) which states: "The President with the approval of the DPR may declare war, make peace and conclude treaties with other countries." In regards of clause "the approval of the DPR", as the function of the DPR is parliament which legislates law, this clause meant that the legal standing of a treaty is equal to the law [9].

Furthermore, the article 32A of Indonesia income tax law and its elucidation states the tax treaty is a special set of law or a lex-specialis law. It is stated that: "The Government is authorized to conclude an agreement with the government of foreign countries for the avoidance of double taxation and the prevention of tax evasion." The elucidation stipulated that "In efforts of promoting economic and trade relationship with other countries, it is necessary to have a special set of law (lex-specialis) which regulates taxing rights of each country covered in the law to provide legal certainty, to avoid double taxation and to prevent tax evasion. Forms and substances of such law refer to the international convention, other regulations, and also the national tax regulation of each country." Therefore, it can be concluded that in any case there are tax regulations in the income tax law that falls into the same area as it stipulated in the tax treaty, the treaty should prevail as it is a lex-specialis law.

\section{Provision in Indonesia's Tax Treaties with Partner States Regarding Dividends}

From the list of contractors from the BPK-RI audit reports, the domicile status of each contractors and it tax treaties mainly are UK and Malaysia. Therefore, it is imperative to analyse the treaties between Indonesia - UK and Indonesia - Malaysia to gain a better understanding of the issue. In the Indonesia-UK treaty branch profit tax falls in the category of tax on dividends in article 10 verse 7 of the treaties, which states:
"Notwithstanding the other provisions of this Agreement, where a company which is a resident of a Contracting State, having a permanent establishment in the other Contracting State, derives profits through that permanent establishment, such profits may be taxed (in addition to the tax which would be chargeable on those profits if they were the profits of a company which was a resident of that other Contracting State) in accordance with the laws of the other Contracting State but the rate of tax so imposed shall not exceed $10 \%$ of the profits of the permanent establishment after pay ment of the income tax on those profits."'[10]

In the regulation above, it is clear that the source state (Indonesia) may impose tax on company profit, which has a $\mathrm{PE}$ in the source state, in addition to the CIT, in accordance to the Indonesia domestic law. However, the rate of tax imposed is limited to $10 \%$ of the profits of the PE after deducted with the CIT.

On the other hand, in the Indonesia-Malaysia treaty, the provision of reduction tariff on dividend is not states exp licitly as in the Indonesia-UK treaty, instead the provision is located in the paragraph 5 of protocol, which basically states that if Indonesia agreed on a treaty with any other State that allow a favourable treatment on the Dividend provision for the PSC on oil and natural gas, then Malaysia resident company would also gain the same benefit. The provision is as follow:

"In connection with Article 10 "Dividends", nothing in this Article shall affect the provisions contained in any production sharing contracts relating to the exploitation and production of oil and natural gas which have been negotiated with the Government of Indonesia or the relevant state oil company of Indonesia, provided that a company which is resident in Malaysia deriving income from a production sharing contract shall not be less favourably treated with respect to tax than that levied on a company of a third state deriving income from a similar production sharing contract."[11]

\section{Case Study: Tax Court Verdict}

After the discussion regarding the legal theory and historical aspect of the tax on dividend between PSC and tax treaty, it is interesting to take a look on to the tax court verdict regarding this issue. As aforementioned above, there are already 9 cases reached final verdicts, 8 sided to the GoI favour whereas 1 verdict agreed to the appellant's argument. We will explore the judges' considerations from both sides. The names of the appellants are not disclosed following the tax courts policy.

From the 8 cases that favour to the GoI, the judges panel considerations are mostly identical, although there are variances in the composition of the legal basis. The considerations are as follows:

1. The judges highlighted article 1320 and 1338 ICC regarding the requirement of an agreement and the legally binding of an agreement for the contracting parties in related to the PSC Section V number 5.2 (r) that states "Contractor shall severally pay to the GoI the income tax including the final tax on profits after tax deduction imposed on it pursuant to the Indonesia income tax law and its implementing regulations." The judges did not agree with the appellant's 
arguments regarding the clause in the Section V number 5.2 (r) PSC which interpreted the clause "Indonesia income tax law and its implementing regulations" contain the applicability of tax treaty rulings as it is not stated explicitly in the contract.

2. At the date of the PSC signed, there were applicable laws and regulations regarding the collection and tax payment procedures for oil and gas PSC contractors which is MoF Ruling KMK-267/1978 which applied since 1 January 1978 and KMK-458/1984 applied since 1 January 1984. Artic le 3 of the KMK-267/1978 states that "CIT liable is $45 \%$ from the taxable income; Tax on Interest, Dividend and Royalty liable is $20 \%$ from taxable income after deducted by CIT", whereas KMK-458/1984 lowered the CIT rate to 35\% while kept the BPT on $20 \%$ after deducted by CIT. The percentage of petroleum production sharing $85 \%: 15 \%$ between Pertamina and Contractor on net revenue (after tax) basis come from political, economy, social, and law process in the oil and gas industry started in the 1970 s and still valid to date. It has been widely known by practitioners, academicians, technocrats and bureaucrats in the industry, which in the law science, the events, circumstances or situation arise typically called notoir.

3. Further, they quote article 1342 ICC stating that "If the wording of an agreement is clear, one shall not deviate from it by way of interpretation". Also, article 1343 ICC states "If the wording of an agreement is open to several interpretations, one shall ascertain the intent of the parties involved rather than be bound by the literal sense of the words." Therefore, the interpretation of a clause in the PSC should be done as intended by the contracting parties. PE PXXXXXXX as the new owner of participating interest should not make its own judgment and interpretation of a clause in the PSC without take notice of the intended meaning.

4. It can be proven that the proportion of oil production share before tax in the PSC year to year changed according to the prevailing income tax law at the signed date of the PSC. The data is as follows:

TABLE II. PROPORTION OF OIL PRODUCTION SHARE

\begin{tabular}{|c|c|c|c|c|c|}
\hline Tax Rate & Pre-1984 & 1984 & 1991 & 1994 & 2001 \\
\hline CIT & \begin{tabular}{|l|}
$45 \%$ \\
\end{tabular} & $35 \%$ & $35 \%$ & $30 \%$ & $30 \%$ \\
\hline $\begin{array}{l}\text { IDRT/BPT (20\% } \\
x(100 \% \text {-CIT) }\end{array}$ & $11 \%$ & $13 \%$ & $13 \%$ & $14 \%$ & $14 \%$ \\
\hline $\begin{array}{l}\text { Total Income } \\
\text { Tax }\end{array}$ & $56 \%$ & $48 \%$ & $48 \%$ & $44 \%$ & $44 \%$ \\
\hline $\begin{array}{l}\text { Production } \\
\text { Share Rate }\end{array}$ & Pre-1984 & 1984 & 1991 & 1994 & 2001 \\
\hline $\begin{array}{l}\text { Net Contractor } \\
\text { Share }\end{array}$ & $15.0000 \%$ & $15.0000 \%$ & $15.0000 \%$ & $15.0000 \%$ & $15.0000 \%$ \\
\hline $\begin{array}{l}\text { Contractor Share } \\
\text { before Tax }\end{array}$ & $\mathrm{X}$ & $\mathrm{X}$ & $\mathrm{X}$ & $\mathrm{X}$ & $\mathrm{X}$ \\
\hline $\begin{array}{l}\text { Less: Total } \\
\text { Income Tax }\end{array}$ & $56 \% \times \mathrm{X}$ & $48 \% \times \mathrm{X}$ & $48 \% \times \mathrm{X}$ & $44 \% \times \mathrm{X}$ & $44 \%$ x X \\
\hline $\begin{array}{l}\text { Net Contractor } \\
\text { Share }(15 \%)\end{array}$ & $44 \% \times \mathrm{X}$ & $52 \% \times \mathrm{X}$ & $52 \% \times \mathrm{X}$ & $56 \% \times \mathrm{X}$ & $56 \% \times \mathrm{X}$ \\
\hline $\begin{array}{l}\text { Gross } \\
\text { Contractor } \\
\text { Share }(X)\end{array}$ & $15 \% / 44 \%$ & $15 \% / 52 \%$ & $15 \% / 52 \%$ & $15 \% / 56 \%$ & $15 \% / 56 \%$ \\
\hline $\begin{array}{l}\text { Gross } \\
\text { Contractor }\end{array}$ & $34.0909 \%$ & $28.8462 \%$ & $28.8462 \%$ & $26.7857 \%$ & $26.7857 \%$ \\
\hline
\end{tabular}

\begin{tabular}{|l|l|l|l|l|l|}
\hline Share (K) & & & & & \\
\hline $\begin{array}{l}\text { Gross Gov } \\
\text { Share (100\%-X) }\end{array}$ & $65.9091 \%$ & $71.1538 \%$ & $71.1538 \%$ & $73.2143 \%$ & $73.2143 \%$ \\
\hline $\begin{array}{l}\text { Add: Total } \\
\text { Income Tax }\end{array}$ & $56 \% \mathrm{x}$ X & $48 \% \mathrm{x} \mathrm{X}$ & $48 \% \mathrm{x}$ X & $44 \% \mathrm{x}$ X & $44 \% \mathrm{x}$ X \\
\hline Tax Revenue & $19.0909 \%$ & $13.8462 \%$ & $13.8462 \%$ & $11.7857 \%$ & $11.7857 \%$ \\
\hline $\begin{array}{l}\text { Net Gov Share } \\
\text { (Gross+Tax) }\end{array}$ & $85.000 \%$ & $85.000 \%$ & $85.000 \%$ & $85.000 \%$ & $85.000 \%$ \\
\hline
\end{tabular}

5. PSC of the appellant include in the 1984-1994 PSC regime with CIT 35\% and BPT 20\%. The gross up production share in the PSC is $71.15 \%: 28.85 \%$. Therefore, if the BPT rate adjusted to the tax treaty rate of $10 \%$, then to maintain the proportion of the production share $85 \%: 15 \%$ of the contracting parties as it agreed before, the share before tax should be changed to $74.359 \%: 25.641 \%$ for GoI and contractor respectively.

Based on the sample verdict above, it is clear that majority of the Tax Court Judges inclined to the argument that the issue is a contractual issue rather than a treaty issue. Since both law, contractual and treaty, are lex-specialis law, the legal standing from both are equal. Thus, the judges decided to consider the contractual nature of the PSC and the historical background in the fiscal regime to reach a decision.

\section{E. Alternative Dispute Resolution for The Issue}

The issue of branch profit tax has been settled partially through litigation process in the Tax Court. As of December 2016, DGT have collected approximately IDR 8.73 Trillion from the issuance of 137 underpayment tax assessment letters and there are 7 contractors that no longer use tax treaty rate for its BPT from previously 26 contractors in 2010[1]. It is likely that those law enforcement effort and the Tax Court rulings influence the contractors' decision. However, interestingly, the dispute resolution that is agreed by both parties in the PSC is only by consultation and arbitration, not litigation.

Consultation and arbitration clause are typically located in the section XI of the PSC. Article 11.2. PSC states that "Disputes, if any, arising between BPMIgas and Contractor relating to this Contract or the interpretation and performance of any of the paragraphs of this Contract shall be settled amicably and persuasively within ninety (90) days after the receipt by one Party of a notice from the other Party of the existence of the dispute". Further, article 11.3 state "Dispute pursuant to clause 11.2 which cannot be settled amicably, shall be submitted to the decision of arbitration". Typically, there are also provisions regarding the chosen language, rules, and location of the arbitration. Currently, 113 PSC choose International Chamber of Commerce (ICC) in France, 193 PSC choose UNCITRAL in the USA, and 10 PSC choose BANI in Indonesia as their arbitration institution.

In Indonesia domestic law, arbitration and alternative dispute resolution is regulated by Law number 30/1999. Article 3 Law 30/1999 states "The District Court shall have no jurisdiction to try disputes between parties bound by an arbitration agreement". However, tax court is beyond the reach of this article, as it is a special court which have absolute competence as it "constitutes the first and last level court in examining and deciding a tax dispute."[12] However, reflecting to the majority of judges' decision in the Tax Court, which acknowledged the BPT issue as a 
contractual obligation over tax dispute. Then it can be assumed that the dispute resolution clause in the PSC regarding the BPT is sue are still active as it covers all kind of dis pute that might arise.

To date, there is no dispute between GoI and contractors regarding execution of PSC that being brought into arbitration, either by Goi or contractor. In 2015, SKK Migas as the GoI representatives have expressed willingness to bring the disputes to arbitration, however, there are lack of legal expertise and financial difficulties to actually realize it. Financial concerns are related to the cost to hired expert lawyers and the risk to bear all of arbitration costs if the claim unsuccessful[13]. On the other hand, consultation method has been done by SKK Migas and the contractors regularly, although there are no quantitative report regarding the result of the consultation efforts.

Costs of international arbitration might seem relatively expensive, however according to survey by CIArb (Chartered Institute of Arbitrators) in 2011 based on 254 arbitrations conducted between 1991 and 2010, the average cost of international arbitration is approximately GBP $1,580,000$, which the claimants bear $12 \%$ more than the respondents [14]. The dominant proportion of the costs are spent for external legal (74\%), whereas only $20 \%$ goes for arbitrator fees and admin istrative expense. If the arbitration costs above compared with the value to be claimed and the legal fees for litigation process, which usually substantial in the petroleum industry, then the costs may seem inexpensive

Moreover, the average duration of international arbitration proceedings is typically a lot shorter than litigation. Based on the reports by 4 international arbitration centre. On average, it takes approximately 11- 16 months. The shortest are SIAC (Singapore) and and HKIAC (Hongkong) which take around 11 months and the longest is LCIA in London which take 16 months to conclude[15]. Domestic arbitration (BANI) is even shorter with $80 \%$ of cases conclude in less than 6 months, and $40 \%$ cases are less than 3 months [16]. Thus, arbitration may actually be a more effective and efficient way in settling a dispute than litigation.

\section{CONCLUSION}

Following the above discussion, it can be concluded that the dispute of branch profit tax between GoI and oil and gas contractors is caused by the separation of tax calculation from the production sharing proportion. It further create the loophole in interpreting the clauses in the PSC regarding tax which deviate from the initial meaning and spark a dualis $\mathrm{m}$ in the legal standing of the PSC. The litigation process in the Tax Court has confirm that PSC is a contractual agreement, and the tax liable is part of the production share, thus it has to take precedence over tax treaty ruling. However, the lengthy process of the litigation which take 3 to 5 years to conclude is causing further delay and more potential income loss.

Reflecting back to the PSC contract which already have the provisions of dispute resolution through consultation and arbitration, it may worth to try settling the dispute through arbitration if the consultation did not produce the expected outcome. Although it may seem relatively expensive, if the chance of winning the award is great as it already supported by other litigation processes, then it may be an answer to settle other outstanding cases, effectively and efficiently.

\section{REFERENCES}

[1] "BPK-RI Audit Report of Central Government Financial Statements of 2016 number 60b/LHP/XV/05/2017 dated 18 May 2017.” [Online]. Available: http://www.bpk.go.id/assets/files/kpp/2016/kpp_2016_14956196 62.pdf. [Accessed: 20-Dec-2017].

[2] M. A. Karim and K. Mills, No Title. 2003.

[3] Zaerudy and E. All, No Title. 1996.

[4] A. Nasir, Sejarah sistem fiskal migas Indonesia. Jakarta: Grasindo, 2014.

[5] Indonesia Law 7/1983 article 17 and article 26(4). .

[6] "No Title." [Online]. Available: http://www.mahkamahkonstitusi.go.id/public/content/persidangan/ put usan/putusan_sidang_Putusan20PUUV2007ttgMIGAStgl 171207.pdf

[7] Indonesian Civil Code article 1320 and 1338.

[8] Tax Treaty Disputes In Indonesia. Cambridge.

[9] B. Manan, "No Title."

[10] Indonesia-UK Tax Treaty, signed Apr 5, 1993, in force Jan 1, 1995. .

[11] Indonesia-Malaysia Tax Treaty, signed Sept 12, 1991, in force Jan 1,1987 .

[12] Article 33 (1) Law 14/20002 concerning Tax Court. .

[13] "No Title." [Online]. Available: http://www.hukumonline.com/berita/baca/lt565e9975e619b/adaselisih-cost-recovery--skk-migas-tak-mampu-tempuh-arbitraseinternasional.

[14] “No Title." [Online]. Available: https://www.intemationalarbitration-attorney.com/cost-of-international-arbitration/.

[15] "No Title." [Online]. Available: https://globalarbitrat ionnews.com/costs-duration-arbit rationsurvey-siac-hkiac-lcia-scc-case-statistics/.

[16] "No Title." [Online]. Available: http://nasional.republika.co.id/berita/nasional/umum/17/11/13/ozc zyw409-ini-tahapan-penyelesaian-sengketa-di-badan-arbitrase. 